\title{
Relationship between Transport Infrastructure
} and Employment: Evidence from the Chinese Inland Provinces under the "One Belt, One Road" Initiative

\author{
Jin-Hui Li ${ }^{1}$ Gwang-Nam Rim $^{2 *} \&$ Chol-Ju An $^{3}$ \\ ${ }^{1}$ Doctor. Research Fellow, Center for North and South Korea Studies, Yanbian University, Yanji, Jilin, China \\ ${ }^{2}$ Professor, Doctor, Statistics Department, Faculty of Economics, Kim II Sung University, Pyongyang, Democratic People's \\ Republic of Korea \\ Distinguished Researcher of Center for North and South Korea Studies, Yanbian University, Yanji, Jilin, China \\ ${ }^{3}$ Professor, Doctor, Foreign Trade Department, Faculty of Economics, Kim II Sung University, Pyongyang, Democratic People's \\ Republic of Korea \\ Distinguished Researcher of Center for North and South Korea Studies, Yanbian University, Yanji, Jilin, China \\ *Corresponding author: kwangnam@126.com, or gn.rim@ryongnamsan.edu.kp \\ https://riiopenjournals.com/index.php/business-perspective-review/index
}

Doi: https://doi.org/10.38157/business-perspective-review.v2i1.103

Citation: Li, J.H., Rim, G.N. \& An, C.J. (2020). Relationship between Transport Infrastructure and Employment: Evidence from the Chinese Inland Provinces under the "One Belt, One Road" Initiative. Business Perspective Review, 2(1), 13-28. Doi: https://doi.org/10.38157/business-perspective-review.v2i1.103

\section{Research Article}

\section{Abstract}

Purpose: This paper discusses the impact of transport infrastructure on employment in the Chinese inland provinces directly affecting by "One Belt, One Road" initiative.

Methods: The authors analyzed the impact of railways and highways- two key elements of transport infrastructure on employment in five Chinese inland provinces directly affected by the "One Belt, One Road" initiative. The data was collected from the National Bureau of Statistics of China and some databases related to "One Belt, One Road" for the period of 2008-2017. Descriptive statistics and graphic presentation approaches were used to analyze the data.

Results: The findings show that there are unclear relationships between transport infrastructure and employment in the inland provinces under study as affected by the "One Belt, One Road".

Implications: Improvement of transport infrastructure as well as other relevant factors in creating jobs should be considered for generating employment in the provinces under study.

Keywords: Transport Infrastructure, Employment, ‘One Belt, One Road' (OBOR), China

\section{Introduction}

"One Belt, One Road" (Hereafter, OBOR) initiative is the most important line for foreign policy in China. In September and October 2013, China's President Xi Jinping proposed the initiative for 
construction of the "Silk Road Economic Belt" and the "Twenty-First-Century Maritime Silk Road" during his visits to Kazakhstan and Indonesia respectively, which is officially referred to as the "One Belt, One Road" (OBOR) initiative (Cheng, 2016; Huang, 2016). What is important in "One Belt, One Road" (OBOR) initiative proposed by China is the Land Road "Silk Road Economic Belt."

The OBOR initiative will contribute in creating jobs in China and concerned countries (National Development and Reform Commission, et al. 2015a). The key element in OBOR initiative is the infrastructural connectivity, and transport infrastructure such as railways, roads, ports, and airports will be a particular focus (Haggai, 2016). These infrastructural elements will stimulate the economic growth in China and affect most of the Chinese provinces. Furthermore, some of the Chinese provinces will be directly affected by the initiative, since the New Silk Road will go through the provinces. In this context, it is required to consider how the transport infrastructure (TI) will affect employment in the Chinese inland provinces directly affected by the initiative. In fact, employment is the indicator reflecting the socio-economic situation and the important factor that affects the people's income and consumption in a given region. Until now, only a few studies on impact of investment in TI on employment have been done. The result of such studies are mixed as follows; (a) TI has a positive impact on employment (For example, Munnell \& Cook, 1990; Dalenberg et al. 1998; Clark \& Murphy, 1996), (b) TI has not significant impact on employment (For example, Fageda \& Gonzalez-Aregall, 2017), (c) TI has positive impact in shortand medium-run but not in long-run (For example, Demetriades \& Mamuneas, 2000), and (d) TI has negative impact on employment in some aspects (For example, Cohen \& Paul, 2004). Many scholars have conducted in-depth studies of impact of TI on employment considering many factors. However, in fact, they do not consider the features of certain regions in their studies. They simply consider the general trend of TI's impact on employment.

Certain country or region has its own features in economic development, which affect employment. Such situation ought to be considered in studying the TI's impact on employment. In particular, how TI contributes to employment under OBOR initiative is one of the interesting issues in China, and thus, studies on relationship between TI and employment have certain significances in management of infrastructural investment under OBOR initiative. From the limitations of previous studies the paper aims to analyze the impact of specific elements of TI on employment in the Chinese inland provinces directly affected by OBOR initiative. Based on research purpose, our paper is organized as follows. In first section, authors discuss the successes of previous studies which analyzed the impact of infrastructure on employment. Second section analyzes the relationship between TI and employment using the data from 2008 to 2017. The rest of the paper discusses the results, discussions, and conclusion.

\section{Previous study on impact of infrastructure on employment}

In the past, several scholars studied the impact of infrastructural investment on employment based on premise that infrastructure and employment are correlated. Previous researchers demonstrated the effects of infrastructure, in particular, TI on employment in different regions and countries using long-term time series data. According to research results, the directions of 
impact of TI on employment are largely divided into three; positive, zero, and negative. Among them, mainstream is positive. For example, Munnell \& Cook (1990) say that deteriorating infrastructure will lead to real job losses throughout the economy. Duffy-Deno \& Dalenberg (1993) find that holding all other factors constant, the effect of a 10 per cent greater level of per capita public capital stock is a 0.6 and 12.9 per cent higher demand for and supply of municipal workers in the short run using a sample of 48 large US cities during the 1970-80 period. Dalenberg et al. (1998) find that state specific road construction is positively correlated with employment increase through research of relation between public capital and state specific employment increase using data from 1972 to 1991 of 48 states in US. Duranton \& Turner (2012) estimate the effects of major roads and public transit on the growth of major cities in the US between 1980 and 2000 and find that a $10 \%$ increase in a city's stock of roads causes about a $2 \%$ increase in its population and employment. Bottaso et al. (2013) find that port traffic promotes the increase of regional employment (including the service and manufacturing sectors) using the samples of 550 regions in 10 European countries. Clark \& Murphy (1996) demonstrated the positive and significant role of highways on employment increase, and Ferrai et al. (2010) found positive impact of port on regional employment. Brueckner (2003) found the significant casual relation between airline traffic and employment in service related industries but not in goods related industries. Blonigen \& Cristea (2012) demonstrated that airline traffic had significant impact on employment in wholesale and retail industries considering the impact of airline traffic on employment in US urban regions. Percoco (2010) mentioned the positive special spillovers of airline traffic on employment for Italian airports. Albalate \& Fageda (2014) find that the density of motorways and the number of air services promote employment growth by drawing on a sample of 182 European regions for the period 2002-2010 and implementing a dynamic panel-data estimator.

In contrary, some scholars mention the zero impact of TI on employment. For example, Fageda \& Gonzalez-Aregall (2017) found that airline and railway had no correlations with industrial employment increase by studying the total, direct, and indirect impacts of given Spanish transport way on industrial employment increase over 1995-2008. Others argue the negative impact of TI on employment. For example, Cohen \& Paul (2004) recognize that TI can increase the labor productivity, and thus, decrease the demand for labor force because there exists the confront relation between road infrastructure and labor power according to US states. Jiwattanakulpaisarn et al. (2009) found that state specific road expansion could hinder the employment in manufacturing sectors using data of 48 US states. In some studies, the positive impact of TI on employment in some aspects and negative impact in other aspects were discussed. For example, Demetriades and Mamuneas (2000) studied the efficiency of public infrastructural capital using data of 12 OECD countries over 1972-1991 period and found that long-run impact of public infrastructural capital is smaller than medium or short-run impact. Discussing the impact of TI on economic growth, some scholars analyzed its effect in correlation with unemployment and other factors. Ylander (2017) conducted the regression analysis using various variables such as railways, highways, unemployment rate, labor productivity, and so on affecting the Gross Regional Products in order to demonstrate that OBOR and its infrastructural projects 
affect the regional economic growth in China. In China, too, several scholars discussed the casual relation between TI and employment.

As seen from analysis of previous studies, TI has diverse influences on employment in several aspects. However, in general, previous studies focus on causal relation between TI investment and employment in whole country or individual industry. Chinese provinces have their own features in economic development due to diverse socio-economic factors, and these ought to be considered in studying the impact of TI on employment. In other words, either TI has positive impact on employment or not according to provinces. It is our view that various factors are affecting the employment due to features of economic development in individual provinces, and thus, increase in employment does not entirely depend on individual TI. This paper focuses on analyzing the impact of infrastructural elements under OBOR initiative on regional employment, and thus, discusses the influences of TI on province's employment in the Chinese provinces directly affected by OBOR initiative.

\section{Material and Methods}

\subsection{Collection of Data}

The OBOR will have a direct effect on five Chinese inland provinces since the route will go through these provinces (National Development and Reform Commission, et al. 2015b). The Provinces include Shaanxi, Gansu, Ningxia Autonomous Region (Hereafter, Ningxia), Qinghai, and Xinjiang Uygur Autonomous Region (Hereafter, Xinjiang). Therefore, we conduct the analysis based on data from 2008 to 2017 for five Chinese inland provinces. Data are from the National Bureau of Statistics of China and various databases. Important elements of TI under study are railways and highways. Furthermore, we use relative values not absolute values regarding TI such as railways and highways in order to ensure the comparability among provinces under study.

This study aims to investigate the relationship between development level of TI and employment in Chinese inland provinces, and thus, it ensures the comparability among provinces which is of much significance. In general, previous studies did not consider region specific features from purpose of studying the whole TI, and thus, they did not bring forward the issue of ensuring the comparability among provinces. This led to wrong conclusion that the larger the absolute value of individual TI is, the higher the development level of certain region is. This means that the magnitude of provinces under study should be considered in analysis in order to ensure the comparability. From this, we will use indicators such as density of railways $\left(\mathrm{km} / 1000 \mathrm{~km}^{2}\right)$ and density of highways $\left(\mathrm{km} / 1000 \mathrm{~km}^{2}\right)$ as they reflect TI's development level. Given that province-wide employment rate in China is not revealed, we use the employment rate in urban units according to inland provinces, which is calculated based on number of sampling population and number of age-specific population collected in sample survey, and number of employed in urban units. And we assume population at working age as population in 15-64 years age bracket. On these assumption, formulating the process of calculating the urban employment rate is as follows: 
$\frac{\text { Number of population aged } 15-64 \text { (by sample survey) }}{\text { Number of population of sample }}=$ ratio of population at working age $(\%) \times$

number of urban population $=$ number of persons at working age in urban units (1)

Employment rate in urban units $(\%)=\frac{\text { Number of employed in urban units }}{\text { Number of persons at working age in urban units }} \times 100$ (2)

Primary data to make above calculations are collected from National Bureau of Statistics of China. Authors collected the data regarding number of population by sample survey (person), number of population at age interval of 15-64 by sample survey, number of urban population (10 000 persons), number of employed in urban units (10 000 persons), length of railways in operation, and length of highways for five Chinese inland provinces directly affecting by OBOR as follows (See Table 1).

Table 1. Province- and year- specific number of population

\begin{tabular}{|c|c|c|c|c|c|c|c|c|c|c|c|}
\hline \multirow[t]{2}{*}{ Province } & \multirow[t]{2}{*}{ Indicator } & \multicolumn{10}{|c|}{ Year } \\
\hline & & 2008 & 2009 & $2010^{e}$ & 2011 & 2012 & 2013 & 2014 & 2015 & 2016 & 2017 \\
\hline \multirow{8}{*}{ Shaanxi } & Population aged & 25147 & 24884 & 24884 & 24457 & 24007 & 23324 & 23204 & 439664 & 23826 & 23190 \\
\hline & ${\text { (person })^{\mathrm{a}}}^{15-64}$ & & & & & & & & & & \\
\hline & $\begin{array}{c}\text { Population } \\
\text { (Sample, person) }\end{array}$ & 33999 & 33504 & 33504 & 31976 & 31315 & 31063 & 31155 & 589346 & 32014 & 31649 \\
\hline & $\begin{array}{c}\text { Urban population } \\
\text { (10000 persons) }\end{array}$ & 1565 & 1621 & 1709 & 1770 & 1877 & 1931 & 1985 & 2045 & 2110 & 2178 \\
\hline & $\begin{array}{c}\text { Number of } \\
\text { employed in } \\
\text { urban units }(10 \\
000 \text { persons) })^{\mathrm{b}}\end{array}$ & 344.39 & 352.39 & 364.8 & 393.7 & 411.22 & 505.33 & 516.52 & 511.84 & 511.39 & 510.39 \\
\hline & $\begin{array}{c}\text { Length of } \\
\text { railways in } \\
\text { operation }(\mathrm{km})^{\mathrm{c}}\end{array}$ & 3200 & 3300 & 4100 & 4100 & 4100 & 4400 & 4500 & 4500 & 4600 & 5000 \\
\hline & $\begin{array}{c}\text { Length of } \\
\text { highways }(\mathrm{km})\end{array}$ & 131000 & 144100 & 147500 & 152000 & 161400 & 165200 & 167100 & 170100 & 172500 & 174400 \\
\hline & $\begin{array}{c}\text { Area } \\
\left(1000 \mathrm{~km}^{2}\right)^{\mathrm{d}}\end{array}$ & & & & & & & & & & 205.6 \\
\hline \multirow[t]{7}{*}{ Gansu } & $\begin{array}{c}\text { Population aged } \\
15-64 \\
\text { (person) }\end{array}$ & 16902 & 17033 & 17033 & 16260 & 15960 & 15813 & 15970 & 29772 & 16049 & 15666 \\
\hline & $\begin{array}{c}\text { Population } \\
\text { (Sample, person) }\end{array}$ & 23739 & 23405 & 23405 & 21908 & 21507 & 21311 & 21381 & 404863 & 21960 & 21720 \\
\hline & $\begin{array}{c}\text { Urban population } \\
\text { (10000 persons) }\end{array}$ & 856 & 891 & 925 & 953 & 999 & 1036 & 1080 & 1123 & 1166 & 1218 \\
\hline & $\begin{array}{c}\text { Number of } \\
\text { employed in } \\
\text { urban units (10 } \\
000 \text { persons) }{ }^{\mathrm{b}}\end{array}$ & 192.55 & 192.98 & 194.3 & 199.29 & 211.33 & 256.65 & 264.74 & 261.76 & 260.96 & 259.22 \\
\hline & $\begin{array}{c}\text { Length of } \\
\text { railways in } \\
\text { operation }(\mathrm{km})^{\mathrm{c}}\end{array}$ & 2400 & 2400 & 2400 & 2400 & 2500 & 2600 & 3400 & 3800 & 4100 & 4700 \\
\hline & $\begin{array}{c}\text { Length of } \\
\text { highways (km) }\end{array}$ & 105600 & 114000 & 118900 & 123700 & 131200 & 133600 & 138100 & 140100 & 143000 & 142300 \\
\hline & Area $\left(1000 \mathrm{~km}^{2}\right)^{\mathrm{d}}$ & & & & & & & & & & 425.8 \\
\hline \multirow[t]{2}{*}{ Qinghai } & $\begin{array}{c}\text { Population aged } \\
15-64 \\
\text { (person) }\end{array}$ & 3576 & 3554 & 3554 & 3568 & 4361 & 3479 & 3592 & 66728 & 3643 & 3559 \\
\hline & $\begin{array}{c}\text { Population } \\
\text { (Sample, person) }\end{array}$ & 5007 & 4934 & 4934 & 4854 & 4782 & 4769 & 4814 & 91611 & 4987 & 4939 \\
\hline
\end{tabular}

17 Published by Research E Innovation Initiative, 3112 Jarvis Ave, Warren, MI 48091, USA 
Business Perspective Review, 2(1), 2020

\begin{tabular}{|c|c|c|c|c|c|c|c|c|c|c|c|}
\hline & $\begin{array}{c}\text { Urban population } \\
\text { (10 } 000 \text { persons) }\end{array}$ & 226 & 234 & 252 & 263 & 272 & 280 & 290 & 296 & 306 & 317 \\
\hline & $\begin{array}{c}\text { Number of } \\
\text { employed in } \\
\text { urban units (10 } \\
000 \text { persons) }\end{array}$ & 47.02 & 50.63 & 52.6 & 60.59 & 61.69 & 64.19 & 63.19 & 62.71 & 63.09 & 63.35 \\
\hline & $\begin{array}{c}\text { Length of } \\
\text { railways in } \\
\text { operation }(\mathrm{km})\end{array}$ & 1700 & 1700 & 1900 & 1900 & 1900 & 1900 & 2100 & 2300 & 2300 & 2300 \\
\hline & $\begin{array}{c}\text { Length of } \\
\text { highways (km) }\end{array}$ & 56600 & 60100 & 62200 & 64300 & 66000 & 70100 & 72700 & 75600 & 78600 & 80900 \\
\hline & $\begin{array}{c}\text { Area } \\
\left(1000 \mathrm{~km}^{2}\right)\end{array}$ & & & & & & & & & & 722.3 \\
\hline \multirow[t]{7}{*}{ Ningxia } & $\begin{array}{c}\text { Population aged } \\
15-64 \\
\text { (person) }\end{array}$ & 3909 & 3953 & 3953 & 4021 & 3888 & 3924 & 4012 & 75315 & 4140 & 4117 \\
\hline & $\begin{array}{c}\text { Population } \\
\text { (Sample, person) }\end{array}$ & 5533 & 5504 & 5504 & 5463 & 5400 & 5399 & 5460 & 103820 & 5666 & 5627 \\
\hline & $\begin{array}{c}\text { Urban population } \\
\text { (10 000 persons) }\end{array}$ & 278 & 288 & 303 & 319 & 328 & 340 & 355 & 369 & 380 & 395 \\
\hline & $\begin{array}{c}\text { Number of } \\
\text { employed in } \\
\text { urban units (10 } \\
000 \text { persons) }\end{array}$ & 57.13 & 58.1 & 59.3 & 60.85 & 67.42 & 72.18 & 73.25 & 73.12 & 70.69 & 71.14 \\
\hline & $\begin{array}{c}\text { Length of } \\
\text { railways in } \\
\text { operation }(\mathrm{km})\end{array}$ & 800 & 900 & 1200 & 1300 & 1300 & 1300 & 1300 & 1300 & 1300 & 1400 \\
\hline & $\begin{array}{c}\text { Length of } \\
\text { highways (km) }\end{array}$ & 2100 & 21800 & 22500 & 24500 & 26500 & 28600 & 31300 & 33200 & 33900 & 34600 \\
\hline & $\begin{array}{c}\text { Area } \\
\left(1000 \mathrm{~km}^{2}\right)\end{array}$ & & & & & & & & & & 66.4 \\
\hline \multirow[t]{7}{*}{ Xinjiang } & $\begin{array}{c}\text { Population aged } \\
15-64 \\
\text { (person) }\end{array}$ & 13660 & 13690 & 13690 & 13860 & 13546 & 13605 & 13657 & 261207 & 14165 & 14114 \\
\hline & $\begin{array}{c}\text { Population } \\
\text { (Sample, person) }\end{array}$ & 19004 & 18979 & 18979 & 18871 & 18630 & 18688 & 18969 & 367631 & 20165 & 20210 \\
\hline & $\begin{array}{c}\text { Urban } \\
\text { population (10 } 000 \\
\text { persons) }\end{array}$ & 845 & 860 & 940 & 962 & 982 & 1007 & 1059 & 1115 & 1159 & 1207 \\
\hline & $\begin{array}{c}\text { Number of } \\
\text { employed in } \\
\text { urban units } \\
\text { (10 000 } \\
\text { persons) }\end{array}$ & 248.17 & 249.42 & 255 & 279.38 & 288.77 & 309.51 & 316.65 & 317.25 & 320.48 & 335.01 \\
\hline & $\begin{array}{c}\text { Length of } \\
\text { railways in } \\
\text { operation }(\mathrm{km})\end{array}$ & 2800 & 3700 & 4200 & 4300 & 4700 & 4700 & 5500 & 5900 & 5900 & 5900 \\
\hline & $\begin{array}{c}\text { Length of } \\
\text { highways (km) }\end{array}$ & 146700 & 1507 & 152800 & 155200 & 165900 & 170200 & 175500 & 178300 & 182100 & 185300 \\
\hline & $\begin{array}{c}\text { Area } \\
\left(1000 \mathrm{~km}^{2}\right)\end{array}$ & & & & & & & & & & 1660 \\
\hline
\end{tabular}

Source: National Bureau of Statistics of China (2019)

Note: a Population data of 2005 are estimates from the national 1\% population sample survey. And data of other years are $1 \%$ national sample survey on population change.

${ }^{\mathrm{b}}$ Data of employed persons in urban units do not include those of private enterprises. 
c Length of Railways in Operation refers to the total length of the trunk line for passenger and freight transportation in full operation or temporary operation calculated the actual length of the period between two stations. Any full or partial lane and above lines, in calculated in the actual length of the first line; tracks, station lines, segments, branch lines and special purpose lines and does not calculate shipping connecting lines of business mileage.

d From http://baike.baidu.com

e Assumed by 2009 year data due to missing sampling data.

These primary data can serve as basis for calculating the indicators to ensure the comparability among provinces in our study.

\subsection{Processing of data and graphic description}

In order to analyze the relationship between physical elements of TI and employment, we calculate the proportion of population at working age, rate of urban employment, and densities of railways and highways according to provinces and years based on formulas (1) and (2), and put these processed data into graphs. Table 2 calculates the proportion of population at working age in provinces under study

Table 2. Province- and year-specific proportion of population at working age (\%)

\begin{tabular}{|llllll|}
\hline Year & Shaanxi & Gansu & Qinghai & Ningxia & Xinjiang \\
\hline 2008 & 0.7396394 & 0.7119929 & 0.7142001 & 0.7064883 & 0.718796 \\
\hline 2009 & 0.7427173 & 0.7277505 & 0.7203081 & 0.7182049 & 0.7213236 \\
\hline 2010 & 0.7427173 & 0.7277505 & 0.7203081 & 0.7182049 & 0.7213236 \\
\hline 2011 & 0.7648549 & 0.7421946 & 0.7350639 & 0.7360425 & 0.7344603 \\
\hline 2012 & 0.7666294 & 0.742084 & 0.9119615 & 0.72 & 0.7271068 \\
\hline 2013 & 0.7508612 & 0.7420112 & 0.729503 & 0.7268013 & 0.7280073 \\
\hline 2014 & 0.7447922 & 0.7469248 & 0.746157 & 0.7347985 & 0.7199642 \\
\hline 2015 & 0.7460202 & 0.7353747 & 0.7283841 & 0.7254383 & 0.7105141 \\
\hline 2016 & 0.7442369 & 0.7308288 & 0.7304993 & 0.7306742 & 0.7024547 \\
\hline 2017 & 0.7327246 & 0.7212707 & 0.7205912 & 0.731651 & 0.6983671 \\
\hline Total & 7.4751932 & 7.3281827 & 7.4569764 & 7.2483039 & 7.1823177 \\
\hline Average & 0.7475193 & 0.7328183 & 0.7456976 & 0.7248304 & 0.7182318 \\
\hline
\end{tabular}

Source: Own calculation

As seen above, we can find that there exist a little differences in proportion of population at working age among provinces. Among 5 inland provinces, Shaanxi has the highest proportion (on average, 0.7475). Describing these data with graph, we can show above situations more clearly (Fig 1). 


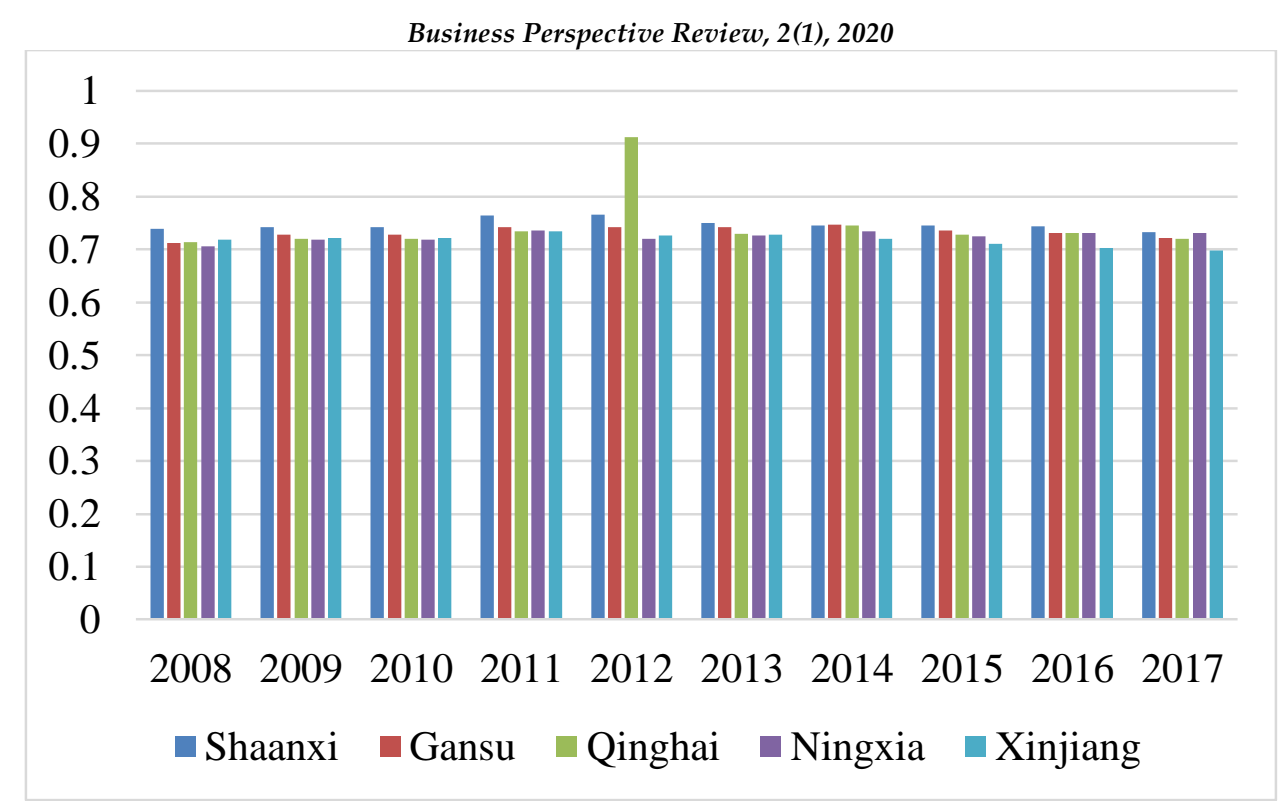

Fig 1. Proportion of population at working age according to provinces (\%)

From fig 1, we can find that although there exist a little differences according to provinces, Qinghai has the highest proportion in 2012. Table 3 calculates province- and year-specific employment rate in urban units

Table 3. Province- and year-specific employment rate in urban units (\%)

\begin{tabular}{|llllll|}
\hline Year & Shaanxi & Gansu & Qinghai & Ningxia & Xinjiang \\
\hline 2008 & 29.751999 & 31.593234 & 29.130924 & 29.088038 & 40.858921 \\
\hline 2009 & 29.269616 & 29.761314 & 30.038192 & 28.088934 & 40.207095 \\
\hline 2010 & 28.740163 & 28.863472 & 28.977901 & 27.249822 & 37.60817 \\
\hline 2011 & 29.081252 & 28.175705 & 31.341525 & 25.915944 & 39.541389 \\
\hline 2012 & 28.577516 & 28.506416 & 24.869632 & 28.548442 & 40.442907 \\
\hline 2013 & 34.852439 & 33.386514 & 31.425503 & 29.209377 & 42.219151 \\
\hline 2014 & 34.937476 & 32.818514 & 29.202506 & 28.080898 & 41.531026 \\
\hline 2015 & 33.549832 & 31.696759 & 29.086041 & 27.315513 & 40.045533 \\
\hline 2016 & 32.565562 & 30.623847 & 28.224048 & 25.459544 & 39.363993 \\
\hline 2017 & 31.981846 & 29.506855 & 27.733099 & 24.615735 & 39.743554 \\
\hline Total & 313.3077 & 304.93263 & 290.02937 & 273.57225 & 401.56174 \\
\hline Average & 31.33077 & 30.493263 & 29.002937 & 27.357225 & 40.156174 \\
\hline
\end{tabular}

Source: Own calculation

Here we find that employment rate in urban units is relatively lower than proportion of population at working age according to provinces. Among 5 provinces, Xinjiang is the highest (on average, 40.156174), other provinces have a little differences. Figure 2 shows the calculation in graphs. 


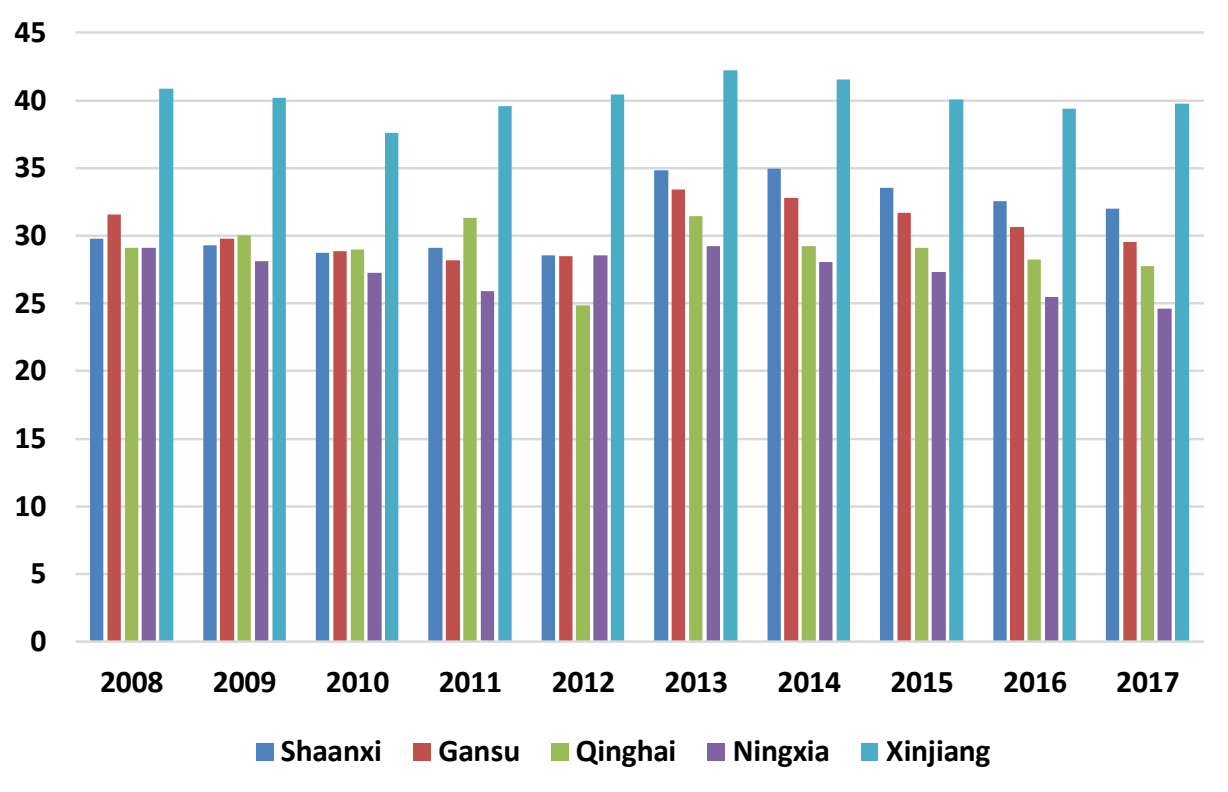

Fig 2. Province- and year-specific employment rate in urban units (\%)

As seen from fig 2, Xinjiang has relatively higher employment rate in urban units, and is followed by Shaanxi. Ningxia has the lowest. Table 4 shows the calculation of the province- and yearspecific density of railways (See Table 4).

Table 4. Province- and year-specific density of railways $\left(\mathrm{km} / 1000 \mathrm{~km}^{2}\right)$

\begin{tabular}{|llllll|}
\hline Year & Shaanxi & Ningxia & Gansu & Xinjiang & Qinghai \\
\hline 2008 & 15.564202 & 12.048193 & 5.636449 & 1.686747 & 2.3535927 \\
\hline 2009 & 16.050584 & 13.554217 & 5.636449 & 2.2289157 & 2.3535927 \\
\hline 2010 & 19.941634 & 18.072289 & 5.636449 & 2.5301205 & 2.6304859 \\
\hline 2011 & 19.941634 & 19.578313 & 5.636449 & 2.5903614 & 2.6304859 \\
\hline 2012 & 19.941634 & 19.578313 & 5.8713011 & 2.8313253 & 2.6304859 \\
\hline 2013 & 21.400778 & 19.578313 & 6.1061531 & 2.8313253 & 2.6304859 \\
\hline 2014 & 21.88716 & 19.578313 & 7.9849695 & 3.313253 & 2.9073792 \\
\hline 2015 & 21.88716 & 19.578313 & 8.9243776 & 3.5542169 & 3.1842725 \\
\hline 2016 & 22.373541 & 19.578313 & 9.6289338 & 3.5542169 & 3.1842725 \\
\hline 2017 & 24.319066 & 21.084337 & 11.038046 & 3.5542169 & 3.1842725 \\
\hline Total & 203.30739 & 182.22892 & 72.099577 & 28.674699 & 27.689326 \\
\hline Average & 20.330739 & 18.222892 & 7.2099577 & 2.8674699 & 2.7689326 \\
\hline
\end{tabular}

Source: Own calculation

As seen above, Shaanxi has the highest density of railways, followed by Ningxia. Figure 3 exhibits the graphical presentation of the data. 


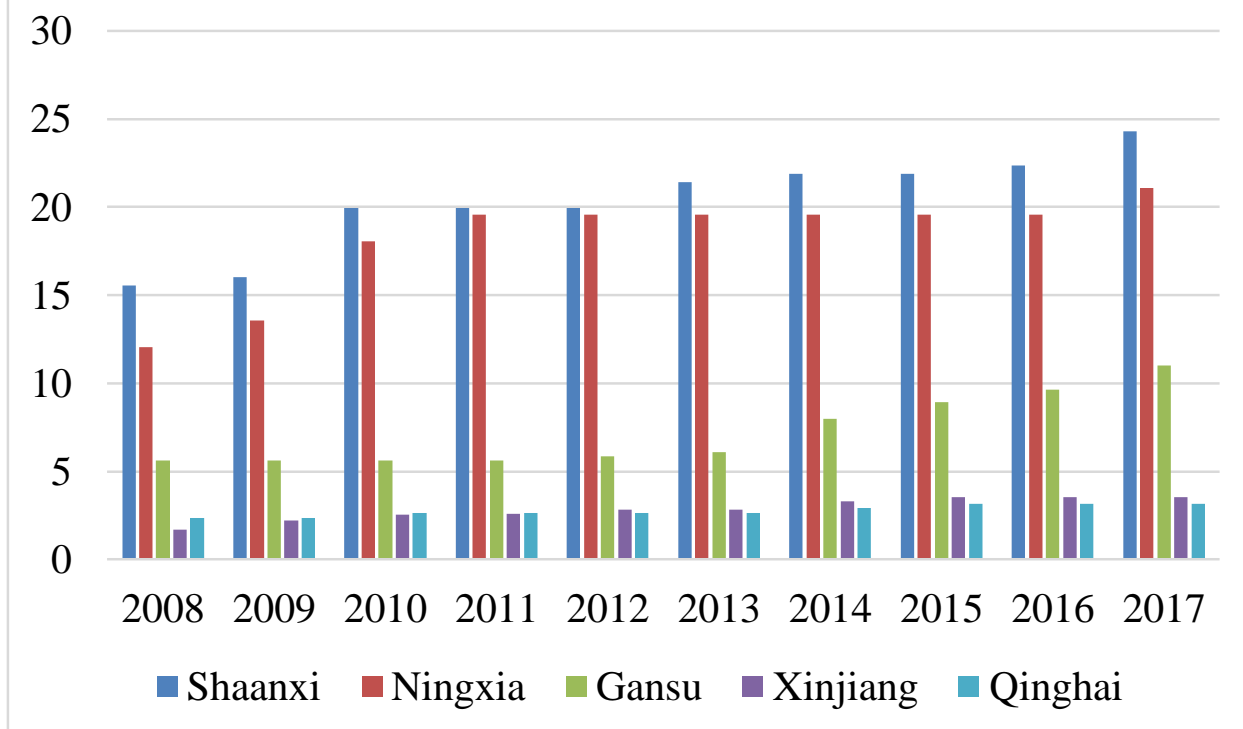

Fig 3. Province- and year-specific density of railways $\left(\mathrm{km} / 1000 \mathrm{~km}^{2}\right)$ Source: Own Calculation

As seen from fig 3. Shaanxi has the highest density of railways, and is followed by Ningxia. Xinjiang and Qinghai have the lowest density. It also shows that the density of railways increased gradually in all provinces. Table 5 depicts the province- and year-specific density of highways

Table 5.Province- and year-specific density of highways $\left(\mathrm{km} / 1000 \mathrm{~km}^{2}\right)$

\begin{tabular}{|llllll|}
\hline Year & Shaanxi & Ningxia & Gansu & Xinjiang & Qinghai \\
\hline 2008 & 637.15953 & 316.26506 & 248.00376 & 88.373494 & 78.360792 \\
\hline 2009 & 700.87549 & 328.31325 & 267.73133 & 90.783133 & 83.206424 \\
\hline 2010 & 717.41245 & 338.85542 & 279.23908 & 92.048193 & 86.113803 \\
\hline 2011 & 739.29961 & 368.9759 & 290.51198 & 93.493976 & 89.021182 \\
\hline 2012 & 785.01946 & 399.09639 & 308.12588 & 99.939759 & 9.1374775 \\
\hline 2013 & 803.50195 & 430.72289 & 313.76233 & 102.53012 & 97.051087 \\
\hline 2014 & 812.74319 & 471.38554 & 324.33067 & 105.72289 & 100.6507 \\
\hline 2015 & 827.33463 & 500 & 329.02771 & 107.40964 & 104.66565 \\
\hline 2016 & 839.00778 & 510.54217 & 335.83842 & 109.6988 & 108.81905 \\
\hline 2017 & 848.24903 & 521.08434 & 334.19446 & 111.62651 & 112.00332 \\
\hline Total & 7710.6031 & 4185.241 & 3030.7656 & 1001.6265 & 869.02949 \\
\hline Average & 771.06031 & 418.5241 & 303.07656 & 100.16265 & 86.902949 \\
\hline
\end{tabular}

Source: Own calculation

While Shaanxi has the highest density of highways, Qinghai and Xinjiang have the lowest. Figure 4 provides a graphical view of the calculations. 


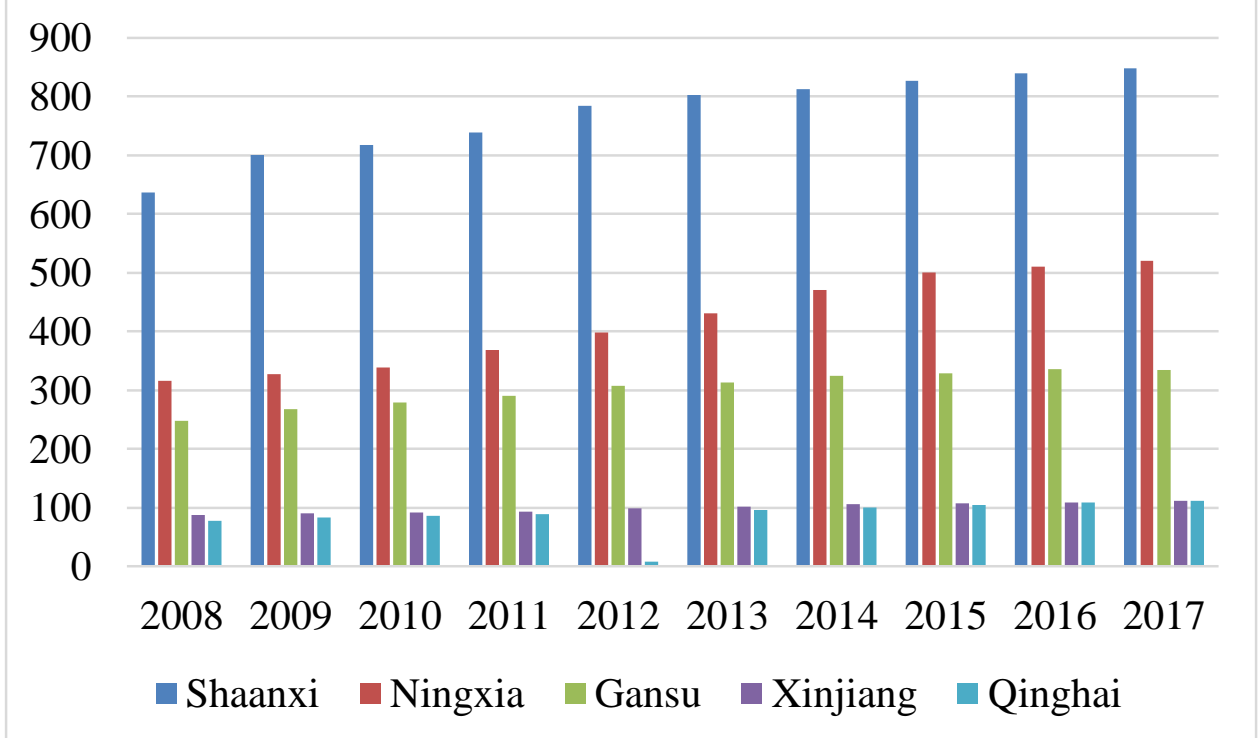

Fig 4. Province- and year-specific density of highways $\left(\mathrm{km} / 1000 \mathrm{~km}{ }^{2}\right)$ Source: Own calculation

On graph, we find that density of highways increases over time in all provinces, and among them, growth rate of Ningxia is the highest.

Above calculation shows the highest or lowest province according to indicators, slowdown in growth of employment rate in urban units, and gradual increase of densities of railways and highways. In other words, TI's development level has been increasing in all provinces over period of 2008-2017. However, this only shows the differences in employment rate and TI's development level among provinces, and thus, it is difficult to analyze the relationships between three indicators with these results. Therefore, it is rational to calculate certain summary statistics such as average and to compare one another in order to facilitate the comparison.

\subsection{Calculation of Statistical Indicators}

From earlier discussions, we could consider the dynamics of three indicators in order to analyze the relationships. This makes it possible to compare three indicators in relation to one another. For comparison, we calculate average values regarding the absolute values of every indicators, and put these values into graph as follows (See Table 6 and Fig 5).

Table 6. Average values of three indicators according to provinces

\begin{tabular}{|cccccc|}
\hline Indicator & Shaanxi & Gansu & Qinghai & Ningxia & Xinjiang \\
\hline Employment rate $(\%)$ & 31.33077 & 30.493263 & 29.002937 & 27.357225 & 40.156174 \\
\hline Density of railways $\left(\mathrm{km} / 1000 \mathrm{~km}^{2}\right)$ & 20.330739 & 7.2099577 & 2.7689326 & 18.222892 & 2.8674699 \\
\hline Density of highways $\left(\mathrm{km} / 1000 \mathrm{~km}^{2}\right)$ & 771.06031 & 303.07656 & 86.902949 & 418.5241 & 100.16265 \\
\hline
\end{tabular}

Source: Own calculation 


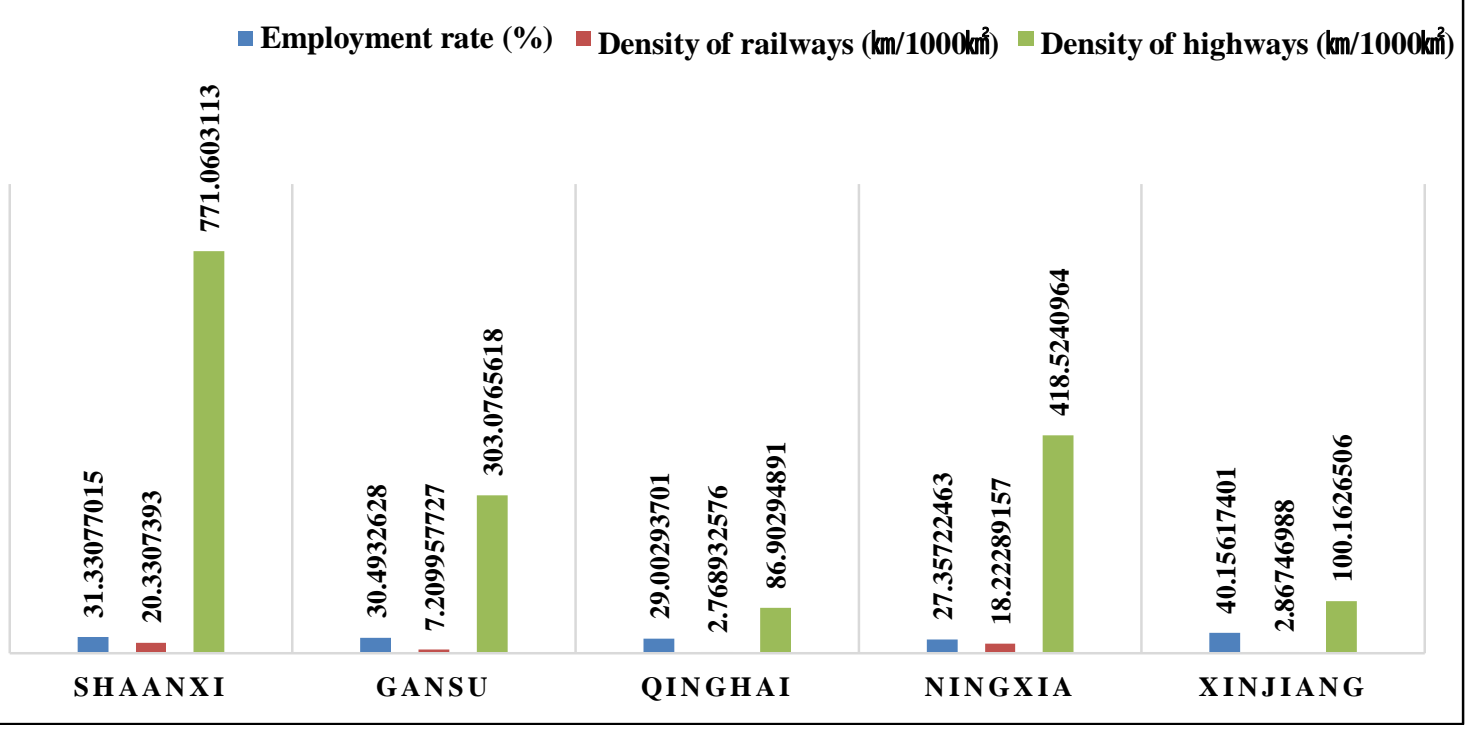

Fig 5. Comparison of average values of three indicators according to provinces

It is seen that figure 5 represents the differences between indicators according to provinces and their relations intuitively. In other words, while Shaanxi is the highest, Qinghai is the lowest regarding the development level of highways. Qinghai and Xinjiang are the lowest in the development level of railways. This indicates the features of natural and geographic conditions in given provinces. However, Xinjiang has the highest employment rate.

\section{Results and discussions}

Results calculated above are significant in showing the representative level of indicators. However, they do not indicate the systematic changes. Considering the indicators in movement, we could analyze the impact of TI on employment. For this, we may calculate the change rates of above indicators as follows (See Tables 7, 8, 9. and 10).

Table 7. Movement of employment rate in urban units (\% growth rate to previous year)

\begin{tabular}{|llllllllllll|}
\hline Year & Shaanxi & $\begin{array}{l}\text { Growth } \\
\text { rate }(\%)\end{array}$ & Gansu & $\begin{array}{l}\text { Growth } \\
\text { rate }(\%)\end{array}$ & Qinghai & $\begin{array}{l}\text { Growth } \\
\text { rate }(\%)\end{array}$ & Ningxia & $\begin{array}{l}\text { Growt } \\
\text { rate } \\
(\%)\end{array}$ & Xinjiang & $\begin{array}{l}\text { Growth } \\
\text { rate }(\%)\end{array}$ \\
\hline 2008 & 29.751999 & & 31.593234 & & 29.130924 & & 29.088038 & & 40.858921 \\
\hline 2009 & 29.269616 & 0.9837865 & 29.761314 & 0.9420154 & 30.038192 & 1.0311445 & 28.088934 & 0.96565 & 40.207095 & 0.9840469 \\
\hline 2010 & 28.740163 & 0.9819112 & 28.863472 & 0.9698319 & 28.977901 & 0.9647019 & 27.249822 & 0.97012 & 37.60817 & 0.9353615 \\
\hline 2011 & 29.081252 & 1.011868 & 28.175705 & 0.9761717 & 31.341525 & 1.0815664 & 25.915944 & 0.95105 & 39.541389 & 1.0514042 \\
\hline 2012 & 28.577516 & 0.9826783 & 28.506416 & 1.0117374 & 24.869632 & 0.7935042 & 28.548442 & 1.10157 & 40.442907 & 1.0227994 \\
\hline 2013 & 34.852439 & 1.2195755 & 33.386514 & 1.171193 & 31.425503 & 1.2636095 & 29.209377 & 1.02315 & 42.219151 & 1.0439198 \\
\hline 2014 & 34.937476 & 1.0024399 & 32.818514 & 0.9829871 & 29.202506 & 0.9292614 & 28.080898 & 0.96136 & 41.531026 & 0.9837011 \\
\hline 2015 & 33.549832 & 0.9602821 & 31.696759 & 0.9658194 & 29.086041 & 0.9960118 & 27.315513 & 0.97274 & 40.045533 & 0.9642317 \\
\hline 2016 & 32.565562 & 0.9706625 & 30.623847 & 0.9661508 & 28.224048 & 0.970364 & 25.459544 & 0.93205 & 39.363993 & 0.9829809 \\
\hline 2017 & 31.981846 & 0.9820757 & 29.506855 & 0.9635254 & 27.733099 & 0.9826053 & 24.615735 & 0.96685 & 39.743554 & 1.0096423 \\
\hline $\begin{array}{l}\text { Average } \\
\text { (\%) }\end{array}$ & & 1.0105866 & & 0.9943814 & & 1.0014188 & & 0.98273 & \\
\hline
\end{tabular}

Source: Own calculation 
Table 8. Movement of density of railways (\% growth rate to previous year)

\begin{tabular}{|lllllllllll|}
\hline Year & Shaanxi & \multicolumn{3}{c}{ Gansu } & \multicolumn{3}{c}{ Qinghai } & \multicolumn{2}{c}{ Ningxia } & \multicolumn{2}{c|}{ Xinjiang } \\
\hline 2008 & 15.5642 & & 5.6364 & & 2.35359 & & 12.0481 & & 1.68674 \\
\hline 2009 & 16.0505 & 1.03125 & 5.6364 & 1 & 2.35359 & 1 & 13.5542 & 1.125 & 2.22891 & 1.32142 \\
\hline 2010 & 19.9416 & 1.24242 & 5.6364 & 1 & 2.63048 & 1.1176471 & 18.0722 & 1.33333 & 2.53012 & 1.13513 \\
\hline 2011 & 19.9416 & 1 & 5.6364 & 1 & 2.63048 & 1 & 19.5783 & 1.08333 & 2.59036 & 1.02380 \\
\hline 2012 & 19.9416 & 1 & 5.87130 & 1.04166 & 2.63048 & 1 & 19.5783 & 1 & 2.83132 & 1.09302 \\
\hline 2013 & 21.4007 & 1.07317 & 6.10615 & 1.04 & 2.63048 & 1 & 19.5783 & 1 & 2.83132 & 1 \\
\hline 2014 & 21.8871 & 1.02272 & 7.98496 & 1.30769 & 2.90737 & 1.1052632 & 19.5783 & 1 & 3.31325 & 1.17021 \\
\hline 2015 & 21.8871 & 1 & 8.92437 & 1.11764 & 3.18427 & 1.0952381 & 19.5783 & 1 & 3.55421 & 1.07272 \\
\hline 2016 & 22.3735 & 1.02222 & 9.62893 & 1.07894 & 3.18427 & 1 & 19.5783 & 1 & 3.55421 & 1 \\
\hline 2017 & 24.3190 & 1.08695 & 11.0380 & 1.14634 & 3.18427 & 1 & 21.0843 & 1.07692 & 3.55421 & 1 \\
\hline $\begin{array}{l}\text { Average } \\
(\%)\end{array}$ & & 1.0531946 & & 1.0813661 & & 1.0353498 & & \multirow{2}{*}{1.0687322} & 1.09070 \\
\hline
\end{tabular}

Source: Own calculation

Table 9. Movement of density of highways (\% growth rate to previous year)

\begin{tabular}{|lllllllllll|}
\hline Year & Shaanxi & $\begin{array}{l}\text { Growth } \\
\text { rate }(\%)\end{array}$ & Gansu & $\begin{array}{l}\text { Growth } \\
\text { rate }(\%)\end{array}$ & Qinghai & $\begin{array}{l}\text { Growth } \\
\text { rate }(\%)\end{array}$ & Ningxia & $\begin{array}{l}\text { Growth } \\
\text { rate }(\%)\end{array}$ & Xinjiang & $\begin{array}{l}\text { Growth } \\
\text { rate }(\%)\end{array}$ \\
\hline 2008 & 637.159 & & 248.003 & & 78.36072 & & 316.26506 & & 88.373494 & \\
\hline 2009 & 700.875 & 1.1 & 267.731 & 1.07954 & 83.2064 & 1.0618375 & 328.31325 & 1.0380952 & 90.783133 & 1.0272665 \\
\hline 2010 & 717.412 & 1.02359 & 279.239 & 1.04298 & 86.1138 & 1.0349418 & 338.85542 & 1.0321101 & 92.048193 & 1.013935 \\
\hline 2011 & 739.299 & 1.03050 & 290.511 & 1.04037 & 89.0211 & 1.0337621 & 368.9759 & 1.0888889 & 93.493976 & 1.0157068 \\
\hline 2012 & 785.019 & 1.06184 & 308.125 & 1.06063 & 91.3747 & 1.0264386 & 399.09639 & 1.0816327 & 99.939759 & 1.0689433 \\
\hline 2013 & 803.501 & 1.02354 & 313.762 & 1.01829 & 97.0510 & 1.0621212 & 430.72289 & 1.0792453 & 102.53012 & 1.0259192 \\
\hline 2014 & 812.743 & 1.01150 & 324.330 & 1.03368 & 100.650 & 1.0370899 & 471.38554 & 1.0944056 & 105.72289 & 1.0311398 \\
\hline 2015 & 827.334 & 1.01795 & 329.027 & 1.01448 & 104.665 & 1.03989 & 500 & 1.0607029 & 107.40964 & 1.0159544 \\
\hline 2016 & 839.007 & 1.01410 & 335.838 & 1.02069 & 108.819 & 1.0396825 & 510.54217 & 1.0210843 & 109.6988 & 1.0213124 \\
\hline 2017 & 848.249 & 1.01101 & 334.194 & 0.99510 & 112.003 & 1.0292621 & 521.08434 & 1.020649 & 111.62651 & 1.0175728 \\
\hline $\begin{array}{l}\text { Average } \\
\text { (\%) }\end{array}$ & & 1.03267 & & 1.03397 & & 1.0405584 & & 1.0574238 & & 1.0264167 \\
\hline
\end{tabular}

Source: Own calculation

Table 10. Comparison of growths of three indicators

\begin{tabular}{|llllll|}
\hline Indicator & Shaanxi & Gansu & Qinghai & Ningxia & Xinjiang \\
\hline Average employment growth rate (\%) & 1.010587 & 0.994381 & 1.001419 & 0.982731 & 0.997565 \\
\hline $\begin{array}{l}\text { Average density of railways growth } \\
\text { rate (\%) }\end{array}$ & 1.053195 & 1.081366 & 1.03535 & 1.068732 & 1.090704 \\
\hline $\begin{array}{l}\text { Average density of highways growth } \\
\text { rate (\%) }\end{array}$ & 1.032674 & 1.033977 & 1.040558 & 1.057424 & 1.026417 \\
\hline
\end{tabular}

Source: Own calculation 
Putting these data into graph is described as follows (Fig 6).

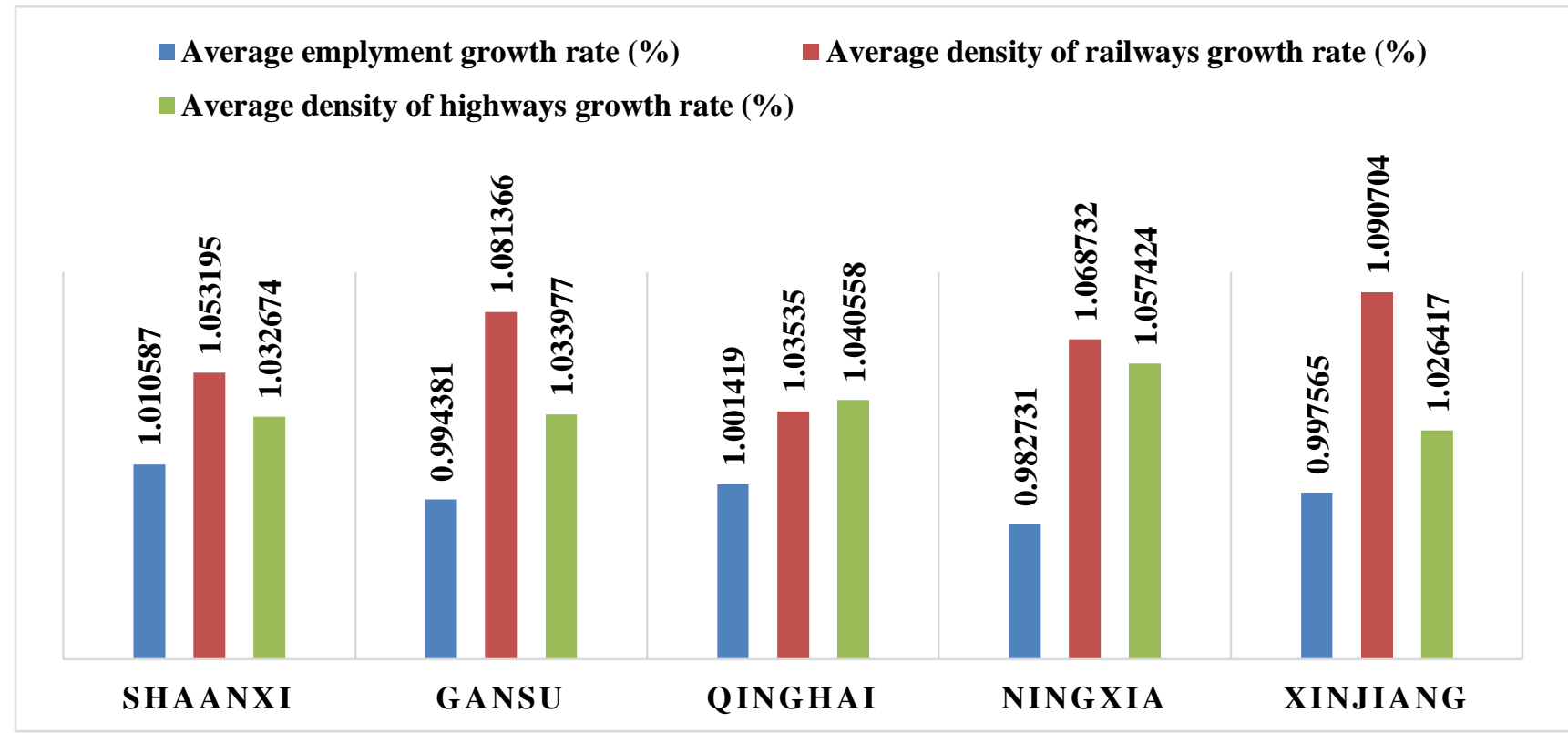

Fig 6. Comparison of average growth rates of three indicators.

Source: Own calculation

Above figure gives the intuitive description on relation between employment and TI's elements with differences in growth rates of three indicators. As seen in figure 6, Shaanxi has the highest average growth rate of employment among the provinces. In other words, as seen earlier, while Xinjiang is the highest in average employment rate, Shaanxi is highest in average growth rate and Ningxia is the lowest in average growth rate of employment. While Xinjiang is the highest in average growth rate of density of railways, Ningxia is the lowest in this indicator. This means that investment in railways increased gradually over past 10 years. Xinjiang is the lowest in density of highways as well as its average growth rate. These facts prove that while in some provinces average growth rate of employment rate depends on those of TI, in other provinces growth of employment rate does not depend on growth rate of TI. This demonstrates that different relationships between three indicators emerge in every provinces.

\section{Conclusion}

This study calculated the indicators such as employment rate in urban units, density of railways, and density of highways and considered the interrelations of these indicators in order to reveal the relation between employment rate and TI's elements. For this, we illustrated the relevance of data processing for the purpose of ensuring comparability among provinces, calculated the employment rate in urban units, density of railways, and density of highways of provinces under study based on data from National Bureau of Statistics of China, and analyzed the relationships between them in terms of statistical indicators. What is important in these procedures is the calculation of averages and graphic description based on them. Analysis by average values of 
indicators is significant in presenting the differences according to provinces, but has limitations in analyzing the relationships among them. From this, we calculated the average growth rates of three indicators and compared. We observed that Shaanxi and Qinghai are similar in average growth rates of three indicators, and this shows that growth of TI affects growth of employment rate in urban units. On the other hand, Xinjiang and Gansu have the largest differences in average growth rates of employment rate and the elements of TI. For example, Xinjiang is the lower in average growth rate of individual TI elements, but province's growth of employment rate is the highest than that of other provinces. This means that TI does not have significant impact on employment. There are also other factors that affect employment. Such analysis of relationship between employment and TI's elements based on calculation of statistical indicators implies that in order to ensure purposeful employment in provinces under study, OBOR investment in TI should be conducted duly.

Author Contributions: Jin-Hui Li conceived the idea and collected data; Gwang-Nam Rim analyzed the data; Chol-Ju An wrote the paper.

Conflict of interest: The authors declare no conflict of interest.

\section{REFERENCES}

Albalate, D., \& Fageda, X. (2014). High-Technology Employment and Transportation: Evidence from the European Regions. Regional studies, 50(9), 1564-1578. Retrieved from: Doi:10.1080/00343404.2015.1041371.

Bottaso, A., Maurizino, C., Claudio, F., Olaf, M., \& Alessio, T. (2013). The impact of port throughput on local employment: Evidence from a panel of European regions. Transport policy, 27, 32-38.

Blonigen, B. A., \& Cristea, A. D. (2012). Airports and urban growth: Evidence from a quasi-natural policy experiment. NBER Working Paper Series, 1-37.

Brueckner, J. K. (2003). Airline traffic and urban economic development. Urban Studies, 40(8), 1455-1469.

Cheng, L. K. (2016). Three questions on China's "Belt and Road Initiative". China Economic Review, 40, 309-13. Retrieved from: https://doi.org/10.1016/j.chieco.2016.07.008.

Cohen J. P., \& Paul, J. M. (2004). Public Infrastructure Investment, Interstate Spatial Spillovers, and Manufacturing Costs. Review of Economics and Statistics, 86(2), 551-560.

Clark, D. E., \& Cristopher, A. M. (1996). Countywide employment and population growth: An analysis of the 1980s. Journal of Regional Science, 36 (2), 235-256.

Demetriades, P., \& Mamuneas, T. (2000). Intertemporal output and employment effects of public infrastructure capital: Evidence from 12 OECD economies. Economic Journal, 110, 687-712.

Dalenberg, D. R., Partridge, M. D., \& Rickman, D. S. (1998). Public Infrastructure: Pork or Jobs Creator? Public Finance Review, 26(1), 24-52.

Duffy-Deno, K. T., \& Dalenberg, D. R. (1993). The municipal wage and employment effects of public infrastructure. Urban Studies, 30(9), 1577-1589. Retrieved from: Doi:10.1080/00420989320081511.

Duranton, G., \& Turner, M. A. (2012). Urban Growth and Transportation. The Review of Economic Studies, 79, 14071440. Retrieved from: http://dx.doi.org/10.1093/restud/rds010

Fageda, X., \& Gonzalez-Aregall, M. (2017). Do All Transport Modes Impact on Industrial Employment? Empirical Evidence from the Spanish Regions, Transport Policy, 55, 70-78.

Ferrai, C., Marco, P., \& Andrea, T. (2010). Ports and Local development: Evidence from Italy. International Journal of Transport Economics, 37(1), 9-30.

Haggai, K. (2016). One Belt One Road Strategy in China and Economic Development in the Concerning Countries. World Journal of Social Sciences and Humanities, 2(1), 10-14. 
Huang, Y. P. (2016). Understanding China's Belt \& Road Initiative: motivation, framework and assessment. China Economic Review, 40, 314-21.

Jiwattanakulpaisarn, P., Noland, R. B., Graham, D. J., \& Polak, J. W. (2009). Highway infrastructure investment and country employment growth: A dynamic panel regression analysis. Journal of regional Science, 49(2), 263-286.

Munnell, A. H., \& Cook, L. M. (1990). How Does Public Infrastructure Affect Regional Economic Performance? New England Economic Review, 1990, 11-33.

National Bureau of Statistics of China. (2019). National data. Retrieved from: http://www.stats.gov.cn/english/.

National Development and Reform Commission, Ministry of Foreign Affairs, and Ministry of Commerce of the People's Republic of China. (2015a). Vision and Proposed Actions on Jointly Building Silk Road Economic Belt and 21st-Century Maritime Rilk Road. from: http://en.ndrc.gov.cn/newsrelease/201503/t20150330_669367.html.

National Development and Reform Commission, Ministry of Foreign Affairs, and Ministry of Commerce of the People's Republic of China. (2015b). Vision and Proposed Actions on Jointly Building Silk Road Economic Belt and 21st-Century Maritime Rilk Road. from: http://en.ndrc.gov.cn/newsrelease/201503/t20150330_669367.html.

Percoco, M. (2010). Airport Activity and Local Development: Evidence from Italy. Urban Studies, 47(11), 2427-2443. Ylander, A. (2017). The impact of 'On Belt, One Road' and its Effects on GDP growth in China. Retrieved from: https://gupea.ub.gu.se/handle/2077/52800. Attribution (CC-BY) license (http://creativecommons.org/licenses/by/4.0/). 